\title{
Bursting of Glacial Lakes-- A Consequence of Global Warming: A Case History from the Lunana Area, Gasa Dzongkhag, Bhutan
}

\author{
ON Bhargava ${ }^{1}$, SK Tangri ${ }^{2}$ and AK Choudhary ${ }^{3}$ \\ 1103 Sector 7, Panchkula 134109, INDIA \\ 23 Sector 33, Chandigarh, INDIA \\ ${ }^{3}$ Resident Geologist, Tala Hydroelectric Project Authority, Tshimalakha, Chimakoti, BHUTAN
}

The lower reaches of the Lunana area expose multiple folded migmatite and biotite gneiss of the Thimphu Group, extensively intruded by granitic and pegmatitic rocks. This sequence in the upper reaches of the Table Mountain is overlain by the Tethyan metasediments.

The straight course of the Pho Chhu between Luggye and Lhedi lakes in the Lunana area is probably controlled by a fault. A N-S strike-slip fault during Quaternary seems to have formed the Raphstreng Lake as a pull apart sag-pond.

Severe hot summers during the year 1994 led to excessive melting of glaciers. The exceptional melting contributed enormous amount of melt water to the lake basins, which caused breach of the morainic dam and consequent enlargement of the outlet of the Luggye Tsho and the Tshopda Tsho. The breach was followed by floods on October 7, 1994,. These floods destabilized the slopes on either bank of the Pho Chhu near Tshopda Tsho outlet making them prone to landslides. The flash floods also eroded the left lateral moraine of the Raphstreng Tsho, which had disturbed the original angle of repose. The Raphstrcng area is also prone to ice avalanches, rock glaciers, surge of which can damage the rim and also cause spillover of water.

The morainic material comprises poorly graded gravel, deficient in finer fraction. The unit weight or in place density of the material and permeability values varies from $17.67 \mathrm{kN} / \mathrm{m}^{3}$ to 19.66 $\mathrm{kN} / \mathrm{m}^{3}$ and 7.39 to 8.36 Lugeon respectively in the Raphstreng Tsho, $24.66 \mathrm{kN} / \mathrm{m}^{3}$ and 1.81 Lugeon in the Thorthormi Tsho and $21.39 \mathrm{kN} / \mathrm{m}^{3}$ and 1.14 Lugeon in the Lyggey Tsho. The permeability values suggested semi-pervious nature of the material. The values of cohesion and friction angle are $0.02 \mathrm{kN} / \mathrm{cm}^{2}$ and 370 respectively.

The mitigating measures suggested were: (i) management of active landslide in the Tshopda-Tsho-Thorthormi Tsho complex, (ii) construction of dykes, check dams and (iii) partial draining of the Raphstreng Tsho complex and construction of dykes and check dams in Thnza-Tshoju complex. Plantation along the slopes, regular monitoring of the lakes, seismic and microclimatic observations are recommended as long term measures. These measures were implemented in the years 1996-97. Since then the lakes of this area have remained intact. 